\section{Stable isotopic evidence for methane seeps in Neoproterozoic postglacial cap carbonates}

\section{Ganqing Jiang ${ }^{1}$, Martin J. Kennedy ${ }^{1}$ \& Nicholas Christie-Blick ${ }^{2}$}

${ }^{1}$ Department of Earth Sciences, University of California, Riverside, California 92521, USA

${ }^{2}$ Department of Earth and Environmental Sciences and Lamont-Doherty

Earth Observatory of Columbia University, Palisades, New York 10964-8000, USA

The Earth's most severe glaciations are thought to have occurred about 600 million years ago, in the late Neoproterozoic era ${ }^{1,2}$. A puzzling feature of glacial deposits from this interval is that they are overlain by 1-5-m-thick 'cap carbonates' (particulate deepwater marine carbonate rocks) associated with a prominent negative carbon isotope excursion ${ }^{3-8}$. Cap carbonates have been controversially ascribed to the aftermath of almost complete shutdown of the ocean ecosystems for millions of years during such ice ages-the 'snowball Earth' hypothesis ${ }^{4,5}$. Conversely, it has also been suggested that these carbonate rocks were the result of destabilization of methane hydrates during deglaciation and concomitant flooding of continental shelves and interior basins ${ }^{3}$. The most compelling criticism of the latter 'methane hydrate' hypothesis has been the apparent lack of extreme isotopic variation in cap carbonates inferred locally to be associated with methane seeps. Here we report carbon isotopic and petrographic data from a Neoproterozoic postglacial cap carbonate in south China that provide direct evidence for methane-influenced processes during deglaciation. This evidence lends strong support to the hypothesis that methane hydrate destabilization contributed to the enigmatic cap carbonate deposition and strongly negative carbon isotopic anomalies following Neoproterozoic ice ages. This explanation requires less extreme environmental disturbance than that implied by the snowball Earth hypothesis ${ }^{4,5}$.

Methane oxidized in sea-floor sediments is hypothesized to have provided both a source for more than $10^{17} \mathrm{~mol}$ of excess $\mathrm{CO}_{3}^{2-}$ driving carbonate precipitation and a plausible explanation for the timing $\left(<10^{5} \mathrm{yr}\right)$ and magnitude of the observed carbon isotope anomaly ${ }^{3}$. This hypothesis gains support from a suite of distinctive sedimentary structures that are found locally within many cap carbonates, and are known collectively only in seep environments $s^{3,6}$.

Carbonate precipitated in modern seeps and in at least some ancient seeps is typically associated with $\delta^{13} \mathrm{C}$ values of less than $-25 \%$ o, and in some cases as low as $-50 \%$ o (refs 9-12). Heavier $\delta{ }^{13} \mathrm{C}$ values ranging from $-24 \%$ to $+6 \%$ are also common in many examples ${ }^{9,10,12}$, depending on the degree of ambient seawater involvement in carbonate precipitation, and as a result of methanogenesis during burial ${ }^{13,14}$. In some cases, pervasive diagenesis results in homogenization of isotopic values, thereby obscuring the isotopic contrast between the host rock precipitated from sea water and seep-related carbonate cements. In Miocene seeps exposed near Santa Cruz, California, $\delta^{13} \mathrm{C}$ values for most of the calcite samples analysed are between $-4 \%$ o to $-10 \%$ (ref. 15). Such homogenization at a scale of millimetres to centimetres is expected for cap carbonates, most of which are now composed of dolomite. The absence of evidence for extreme isotopic variation in any cap carbonate, for which there is now a substantial global data set $^{3-5,6-8,16}$, has nevertheless been viewed as a serious shortcoming. a
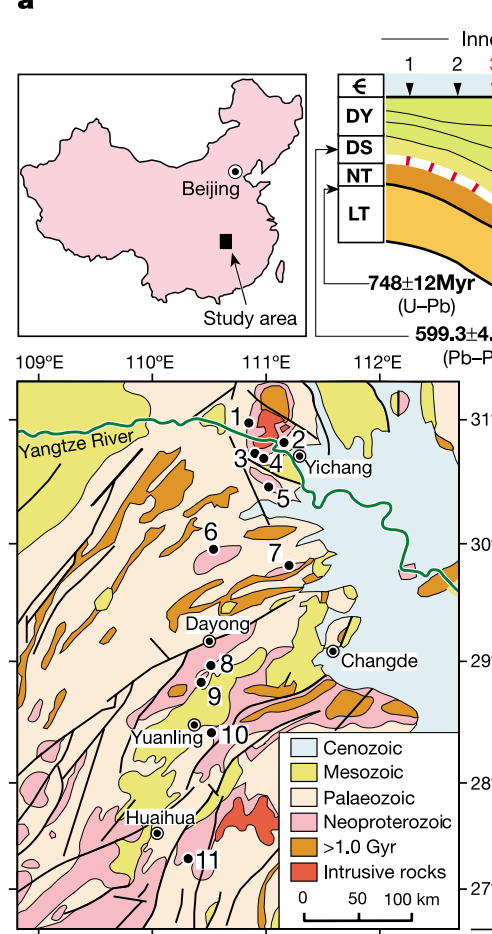

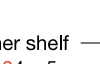

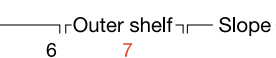
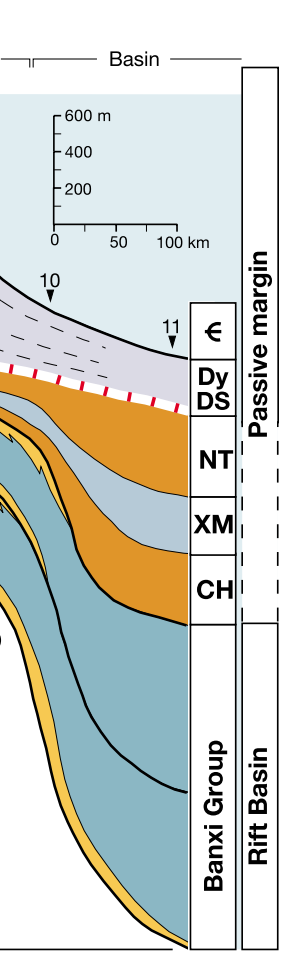

b

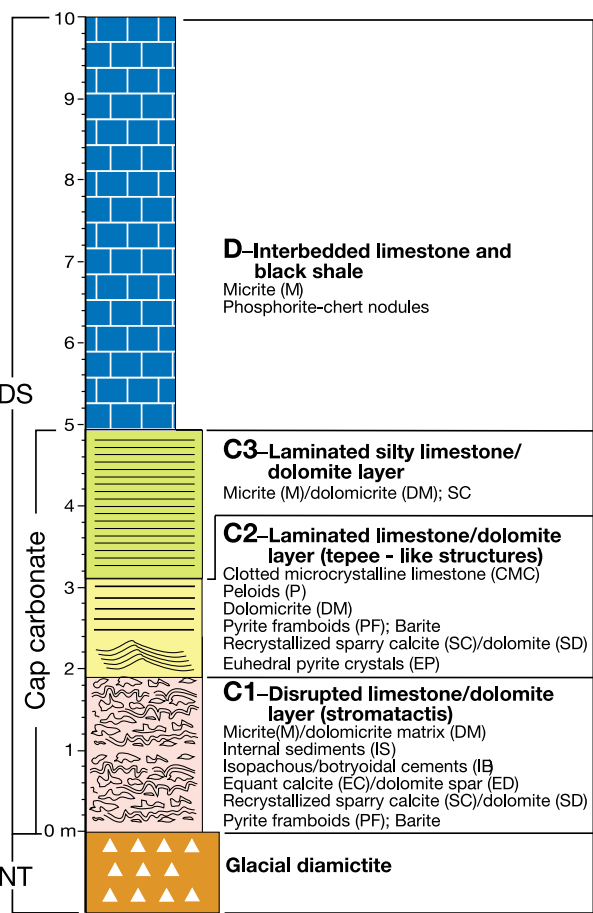

Figure 1 Stratigraphy and cap carbonate microfacies. a, Stratigraphic cross-section of the Yangtze platform in south China; $\mathbf{b}$, summary of microfacies in the cap carbonate. Section numbers matching those in Figs 3 and 4 are in red. Note that the cap carbonate and overlying deposits are preferentially dolomitized in inferred deeper-water sections (Fig. 4). 
To determine the degree to which diagenesis has obscured distinctive isotopic signals imparted by methane-related processes, we conducted a detailed isotopic and petrographic study of seeplike features in the cap carbonate that overlies the glaciogenic Nantuo Formation in the Yangtze platform of south China (Fig. 1a). Although this cap carbonate is in many respects typical of such carbonates globally, it is notable for its unusually low thermal maturity, degree of textural preservation, localized retention of calcite mineralogy, and abundance of well-exposed sections in a platform to basin transect. The Nantuo Formation is the younger of two Neoproterozoic glacial diamictite units preserved within a rift to passive margin succession (Fig. 1a), and is inferred to have an age greater than $\sim 600 \mathrm{Myr}$ (refs 17,18 ). It underlies shale and limestone of the Doushantuo Formation, in which some of the earliest animal fossils have been identified ${ }^{18}$.

Located at the base of the Doushantuo, the 3-5-m-thick cap carbonate contains three lithologically distinguishable but laterally variable limestone and dolomite units (Fig. 1b): a basal layer, 1.0$1.9 \mathrm{~m}$ thick, which is strongly disrupted and cemented (C1), a middle, laminated layer, less than $1 \mathrm{~m}$ thick, with local 'tepee-like' structures (C2), and an upper layer, 1.5-2 m thick, composed of thinly laminated silty limestone and dolomite (C3). Irregular cavities formed by subhorizontal extension of micritic crusts, and filled with multiple generations of fringing (commonly botryoidal) cements, resemble features referred to as stromatactis in some ancient methane-seep deposits ${ }^{10,12}$. Structures described here as tepee-like are of positive relief and from $1-3 \mathrm{~m}$ wide and $<1 \mathrm{~m}$ high, composed of laminated micrite and dolomicrite with layer-parallel sheet cracks, and cored by broken and brecciated host carbonate. Voids in these structures are lined by fringing botryoidal and clotted cements with pyrite framboids (Fig. 2), including radiating blade-shaped crystals of barite $(<5 \mathrm{~mm}$; mostly replaced by calcite), and they are filled at least partially by internal sediments. We infer on this basis that the structures are syn-sedimentary, and that the voids remained open to the sea floor during development.

Isotopic analysis of limestone peloids, clots and fringing cements within and above the tepee-like structures where they are best preserved (location 3 in Fig. 1) reveals highly variable $\delta^{13} \mathrm{C}$ values, ranging from $+5 \%$ o to $-41 \%$ (Fig. 3 ). These data represent, to our knowledge, the first direct geochemical support for deposition in the vicinity of a methane seep. Carbon isotopic values as low as $-41 \%$ in carbonate carbon are known only from carbonate precipitation associated with the oxidation of methane, the carbon isotopic composition of which is the lightest known in nature ${ }^{11}$. The documented variability of carbon isotopic values is characteristic of seep facies ${ }^{9-12}$. The strong inverse correlation with $\delta^{18} \mathrm{O}\left(R^{2}=0.93\right.$, $n=16$; Fig. 3 ) indicates that the most negative $\delta^{13} \mathrm{C}$ values, at least, approach a primary value ${ }^{13,14}$

Isotopically heavy $\delta^{13} \mathrm{C}(+0.95$ to $+4.98 \%$ o $)$ and $\delta^{18} \mathrm{O}(-1.1$ to $+3.0 \%$ ) values (interval C2) and abrupt excursions (each defined by several data points) in $\delta^{13} \mathrm{C}\left(-4.7\right.$ to $+4.7 \%$ ) and $\delta^{18} \mathrm{O}(-12.2$ to $-1.5 \%$ ) (interval C3) above the tepee-like structures reinforce the link to methane-related phenomena. They are consistent with either microbially mediated methane metabolization ${ }^{13,14}$ or with the decomposition of gas hydrates during burial diagenesis ${ }^{10,13,14}$. Methane would have been partially metabolized by bacterial sulphate reduction to produce monosulphides and alkalinity ${ }^{19}$, a process that is consistent with the presence of framboidal pyrite in cements (Fig. 2a and c). The presence of barite reinforces similarities with other cap carbonate deposits ${ }^{3,5}$ and modern seeps $^{20}$, and has been linked to massive dissociation of methane hydrates at the Late Palaeocene Thermal Maximum (LPTM) ${ }^{21}$.

While this cap carbonate provides clear if local evidence for methane seeps, it also opens a window into the modification of the isotopic signature of cap carbonates through diagenesis. Carbon and oxygen isotope values from interval C2 in Fig. 3 fall on a line between a methane-influenced end member $\left(-41 \%{ }_{0} \delta^{13} \mathrm{C} ;-4.3 \%\right.$ $\left.\delta^{18} \mathrm{O}\right)$ and spar-filling tectonic fractures $\left(-3.5 \% \delta^{13} \mathrm{C} ;-13.5 \%\right.$ $\delta{ }^{18} \mathrm{O}$ ). Mixing along this line implies partial alteration of the highly negative values of the seep facies towards a regional diagenetic fluid value preserved in late-stage cross-cutting veins. More pervasively dolomitized deeper-water sections (Fig. 4) display none of the

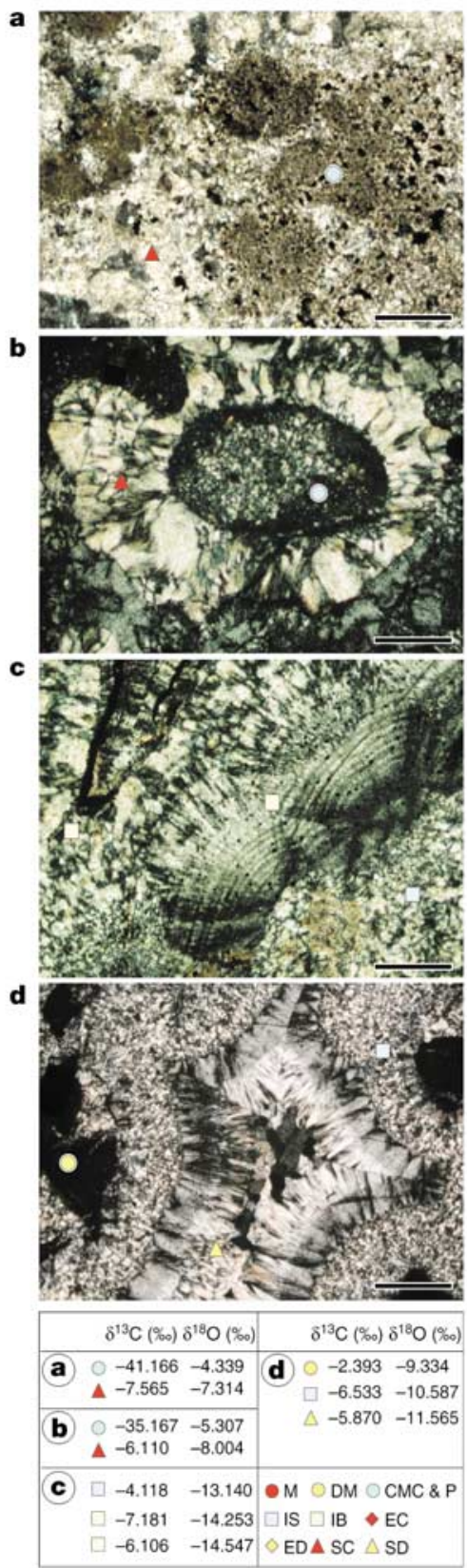

Figure 2 Cap carbonate texture and isotopic composition. a, Clots surrounded by sparry calcite containing framboidal pyrite (small black spots). b. Peloids surrounded by recrystallized calcite spar. c, Partially recrystallized internal sediment and botryoidal cement with radial aragonite fabric now replaced by dolomite. Small black spots within cement are pyrite framboids. $\mathbf{d}$, Brecciated dolomicrite matrix and microcrystalline internal sediment partially filling cavity. Remaining space is filled by sparry dolomite. $\mathbf{a}$ and b are from interval C2 in Fig. 3; $\mathbf{c}$ and $\mathbf{d}$ are from intervals $\mathrm{C} 1$ and C2 in Fig. 4b. Isotopic values of microsamples are listed in table at bottom. Symbols indicate sample location but not sample size. Scale bar, $400 \mu \mathrm{m}$. Plane-polarized light. See Fig. 1b for microfacies abbreviations. 


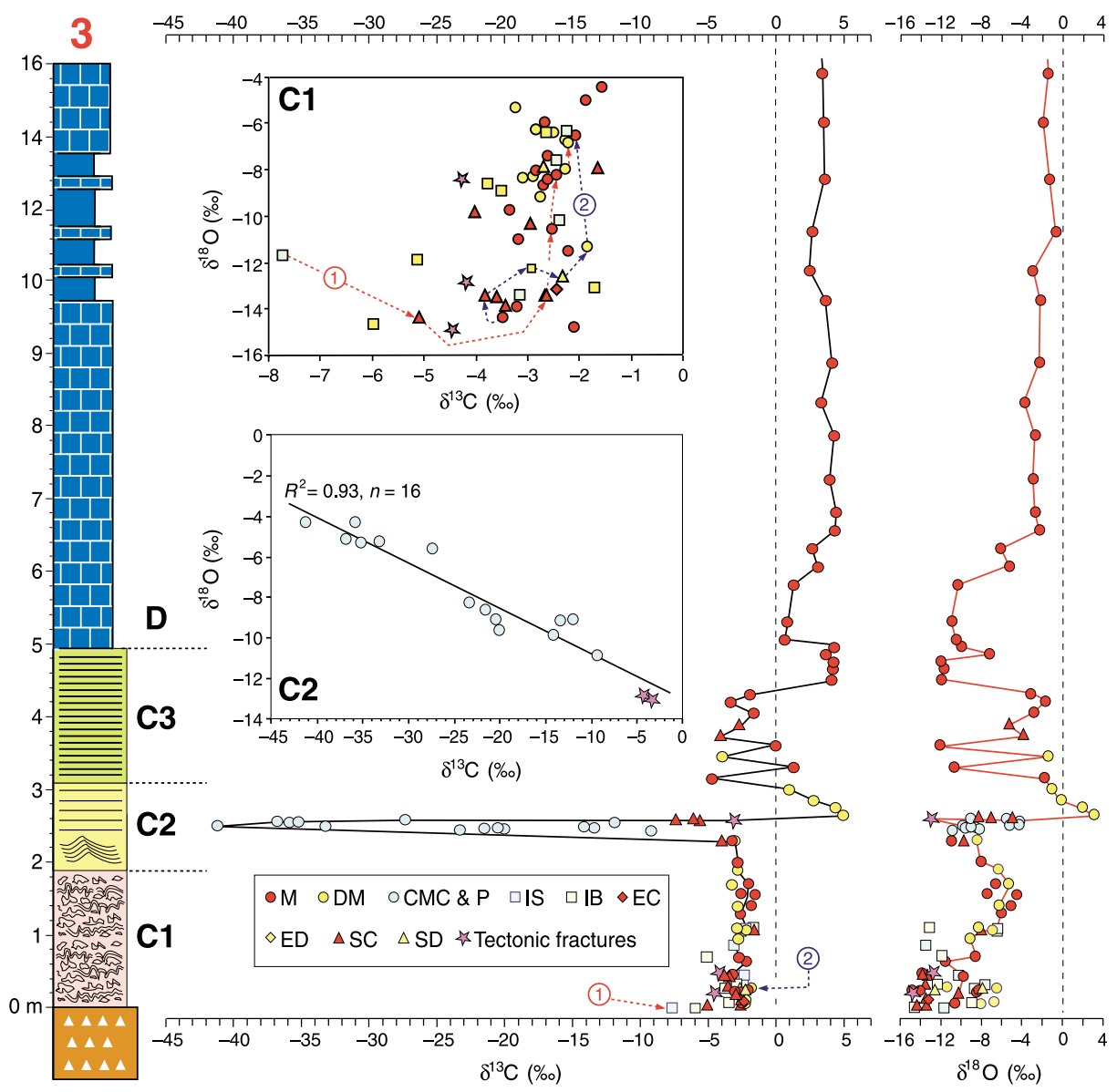

Figure 3 Isotopic composition of cap carbonate from section 3 in Fig. 1a. Carbon isotopic values ranging from $-41 \%$ to $+5 \%$ in $\mathrm{C} 2$ are inferred to indicate methane seeps. Connected points in $\delta^{13} \mathrm{C}-\delta^{18} 0$ crossplot for interval $\mathrm{C} 1$ are microsamples from individual polished slabs $\left(<10 \times 10 \mathrm{~cm}^{2}\right)$, stratigraphically located as indicated. See Fig. 1b for microfacies abbreviations. extreme isotopic variability seen in Fig. 3, even though the same distinct fringing botryoidal, pyrite-bearing cements and tepee-like structures are present also in those sections. The $1-3 \%$ o variation in $\delta^{13} \mathrm{C}$ between sections and covariance between $\delta^{13} \mathrm{C}$ and $\delta^{18} \mathrm{O}$ $\left(R^{2}=0.81, n=26\right.$; Fig. $\left.4 \mathrm{a}\right)$, and variability of up to $3-5 \%$ o between matrix and cements at millimetre (Fig. $2 \mathrm{c}$ and d) and centimetre scales (Figs 3 and 4 ) suggest substantial diagenetic modification of the isotopic signature for the majority of samples, possibly through dolomitization. This raises questions about the retention of primary isotopic values of dolomitized cap carbonates.

Our data indicate a spatial association between methane-seep sedimentary features and the unusually large global isotopic excursion $\left(-4 \% \text { o to }-7 \% \text { o shift in } \delta^{13} \mathrm{C}\right)^{3,5,7,8}$. These seep-like facies are preserved only locally within cap carbonates, consistent with either isolated sources or discrete pathways for methane. However, such facies are also widespread and, in all of the examples known to us, the distinctive structures and textures are localized stratigraphically within the lower portion of the cap carbonate. This precludes the interpretation of these seeps as surface expressions of long-lived hydrocarbon systems. In the light of our new data, the most plausible explanation for the broad but stratigraphically restricted distribution of interpreted methane seeps and the carbon isotopic signature of cap carbonates in general is that they both relate to the postglacial destabilization of gas hydrates.

Mass-balance considerations ${ }^{22}$ for a $-4 \%$ to $-7 \%{ }^{13} \mathrm{C}$ excursion imply the addition of $4.0 \times 10^{18} \mathrm{~g}$ to $7.4 \times 10^{18} \mathrm{~g}$ of ${ }^{13} \mathrm{C}$-depleted $\mathrm{CH}_{4}$ to the exchangeable carbon reservoir. This is equivalent to between $\sim 28 \%$ and $\sim 53 \%$ of the estimated modern gas-hydrate pool. Given estimates of changes in that pool of $14 \%$ for the LPTM $^{22,23}$ and $14-24 \%$ for the Jurassic Oceanic Anoxic Event ${ }^{24}$, late Neoproterozoic cap carbonates are inferred to represent the largest hydrate-dissociation event in Earth's history.

An unresolved issue concerns the relative roles of two discrete components of the gas-hydrate inventory ${ }^{3}$. Although two orders of magnitude smaller than the marine hydrate pool today ${ }^{25}$, the terrestrial permafrost pool would have been substantially larger during times of extreme Neoproterozoic glaciation, and less sensitive than marine hydrates to the trade-off between increasing temperature and rising pressure (water depth), which may stabilize marine hydrates during times of postglacial sea-level rise. However, inferred seep-related structures and textures are present in the cap carbonate of south China as far south as Huaihua (location 11 in Fig. 1a), where facies and a greatly expanded thickness of underlying glaciogenic diamictite $(>500 \mathrm{~m})$ suggest accumulation in a marine basin that was never subaerially exposed. Similar features are also observed in slope facies of the Congo craton in Namibia ${ }^{3,26}$. This raises the possibility that postglacial warming was sufficiently great even in the deep ocean to destabilize the entire gas-hydrate inventory. If methane hydrates play a role in the global carbon cycle 


\section{a}

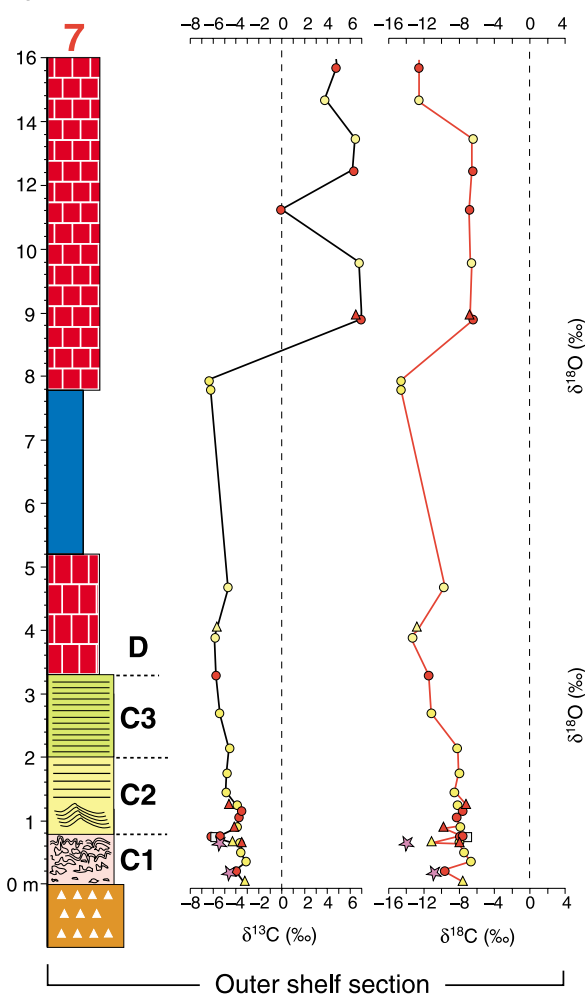

Outer shelf section $\bullet M \circ D M \quad O C M C \& P \quad \square I S \quad \square I B \otimes E C$ $\diamond \mathrm{ED} \quad \triangle \mathrm{SC} \quad \triangle \mathrm{SD}$ ₹Tectonic fractures

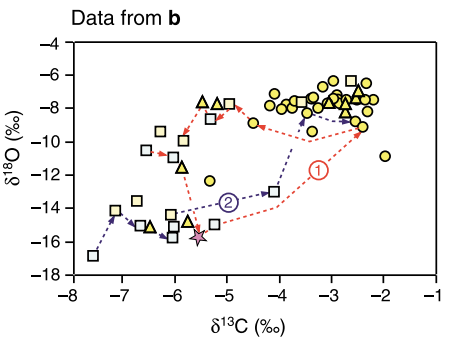

Data from a

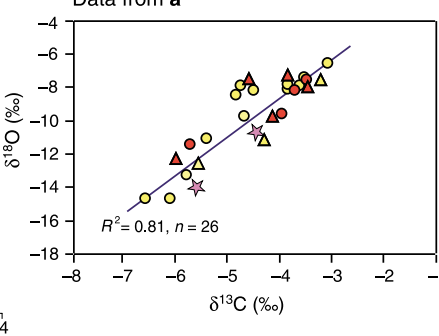

b

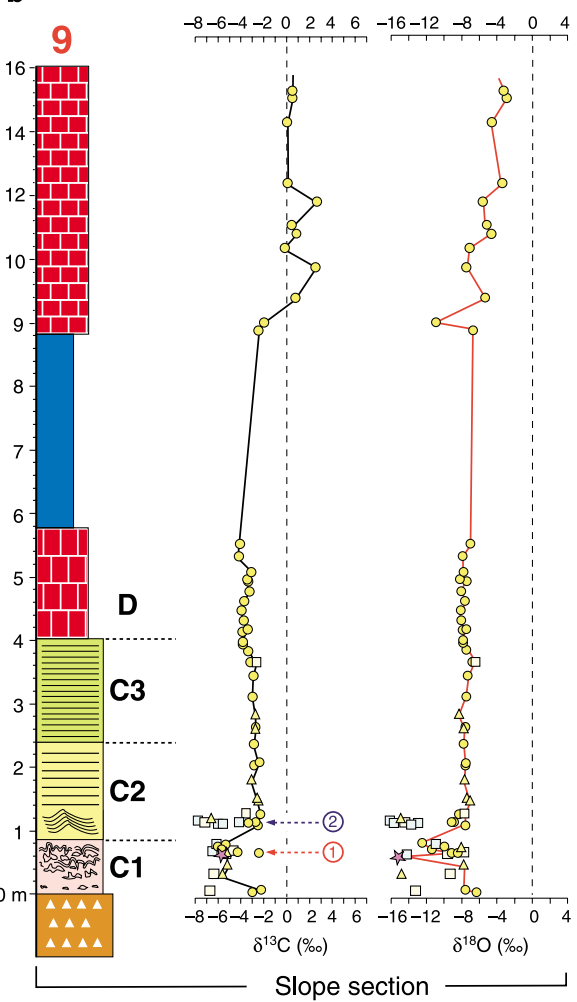

Figure 4 Isotopic composition of cap carbonate from sections 7 and 9 in Fig. 1a. a, Section $7 ; \mathbf{b}$, section 9. Carbon isotopic values are less variable than in Fig. 3. A systematic difference in $\delta^{13} \mathrm{C}$ of $1-3 \%$ between the sections, from interval $\mathrm{C} 2$ to lower part of interval $D$, suggests diagenesis. Connected points in the $\delta^{13} \mathrm{C}-\delta^{18} 0$ crossplot (interval $\mathrm{C} 1$ to lower D) for section 9 are microsamples from polished slabs $\left(<10 \times 10 \mathrm{~cm}^{2}\right)$, stratigraphically located as indicated. See Fig. 1b for microfacies abbreviations. and climate change, as increasingly appears to be the case, Neoproterozoic geology offers a unique opportunity for investigating their influence, along with an important new aspect of the physical context in which metazoans first appear in the fossil record.

\section{Methods}

Petrographic microscopy, cathodoluminescence (CL), and scanning electron microscopy (SEM) were used for petrographic characterization. Powders $(0.5-5 \mathrm{mg})$ were obtained from polished slabs using $0.5-1.2-\mathrm{mm}$-diameter microdrills after petrographic study. Sample powders were reacted with $100 \%$ phosphoric acid at $50{ }^{\circ} \mathrm{C}$ for $2 \mathrm{~h} \cdot \delta^{13} \mathrm{C}$ and $\delta^{18} \mathrm{O}$ were determined at the University of California, Riverside, and are reported using the standard $\delta$-notation compared to PDB. Precision of an internal standard for both $\delta^{13} \mathrm{C}$ and $\delta^{18} \mathrm{O}$ was $\pm 0.2 \%$ o $(n=25)$. Key samples were reanalysed at the University of California, Davis, as a check of reproducibility. Results from the two laboratories agree within $0.5 \%$ for $\delta^{13} \mathrm{C}$ and $0.7 \%$ for $\delta^{18} \mathrm{O}$

Received 22 June; accepted 10 November 2003; doi:10.1038/nature02201.

1. Crowell, J. C. Pre-Mesozoic ice ages: their bearing on understanding the climate system. Mem. Geol. Soc. Am. 192 (1999).

2. Sohl, L. E., Christie-Blick, N. \& Kent, D. V. Paleomagnetic polarity reversals in Marinoan (ca $600 \mathrm{Ma}$ ) glacial deposits of Australia: implications for the duration of low-latitude glaciations in Neoproterozoic time. Geol. Soc. Am. Bull. 111, 1120-1139 (1999).

3. Kennedy, M. J., Christie-Blick, N. \& Sohl, L. E. Are Proterozoic cap carbonates and isotopic excursions a record of gas hydrate destabilization following Earth's coldest intervals? Geology 29, 443-446 (2001).

4. Hoffman, P. F., Kaufman, A. J., Halverson, G. P. \& Schrag, D. P. A Neoproterozoic snowball Earth. Science 281, 1342-1346 (1998).

5. Hoffman, P. F. \& Schrag, D. P. The snowball Earth hypothesis: testing the limits of global change. Terra Nova 14, 129-155 (2002).

6. Kennedy, M. J. Stratigraphy, sedimentology, and isotopic geochemistry of Australian Neoproterozoic postglacial cap dolostones: deglaciation, $\delta^{13} \mathrm{C}$ excursions, and carbonate precipitation. J. Sedim. Res. 66, 1050-1064 (1996).

7. Kennedy, M. J., Christie-Blick, N. \& Prave, A. R. Carbon isotopic composition of Neoproterozoic glacial carbonates as a test of paleoceanographic models for snowball Earth phenomena. Geology 29, 1135-1138 (2001).
8. James, N. P., Narbonne, G. M. \& Kyser, T. K. Late Neoproterozoic cap carbonates: Mackenzie Mountains, northwestern Canada: precipitation and global glacial meltdown. Can. J. Earth Sci. 38, 1229-1262 (2001).

9. Stakes, D. S., Orange, D., Paduan, J. B., Salamy, K. A. \& Maher, N. Cold-seeps and authigenic carbonate formation in Monterey Bay, California. Mar. Geol. 159, 93-109 (1999).

10. Peckmann, J., Goedert, J. L., Thiel, V., Michaelis, W. \& Reitner, J. A compressive approach to the study of methane-seep deposits from the Lincoln Creek Formation, western Washington State, USA. Sedimentology 49, 855-873 (2002).

11. Cavagna, S., Clari, P. \& Martire, L. The role of bacteria in the formation of cold seep carbonates: geological evidence from Monferrato (Tertiary, NW Italy). Sedim. Geol. 126, 253-270 (1999).

12. Kauffman, E. G., Arthur, M. A., Howe, B. \& Scholle, P. A. Widespread venting of methane-rich fluids in Late Cretaceous (Campanian) submarine springs (Tepee Buttes), Western Interior seaway, U.S.A. Geology 24, 799-802 (1996).

13. Irwin, H., Curtis, C. \& Coleman, M. Isotopic evidence for source of diagenetic carbonates formed during burial of organic-rich sediments. Nature 269, 209-213 (1977).

14. Gautier, D. L. \& Claypool, G. E. Interpretation of methanic diagenesis in ancient sediments by analogy with processes in modern diagenetic environments. Mem. Am. Assoc. Petrol. Geol. 37, 111-123 (1984).

15. Aiello, I. W., Garrison, R. E., Moore, J. C., Kastner, M. \& Stakes, D. S. Anatomy and origin of carbonate structures in a Miocene cold-seep field. Geology 29, 1111-1114 (2001).

16. Grotzinger, J. P. \& Knoll, A. H. Anomalous carbonate precipitates: is the Precambrian the key to the Permian? Palaios 10, 578-596 (1995).

17. Barfod, G. H. \& Baker, J. New Lu-Hf and Pb-Pb age constraints on the earliest animal fossils. Earth Planet. Sci. Lett. 201, 203-212 (2002).

18. Xiao, S., Zhang, Y. \& Knoll, A. H. Algae and embryos in a Neoproterozoic phosphorite. Nature 391, 553-558 (1998).

19. Boetius, A. et al. A marine microbial consortium apparently mediating anaerobic oxidation of methane. Nature 407, 623-626 (2000).

20. Greinert, J., Bollwerk, S. M., Derkachev, A., Bohrmann, G. \& Suess, E. Massive barite deposits and carbonate mineralization in the Derugin Basin, Sea of Okhotsk: precipitation processes at cold seep sites. Earth Planet. Sci. Lett. 203, 165-180 (2002).

21. Dickens, G. R., Fewless, T., Thomas, E. \& Bralower, T. J. Excess barite accumulation during the Palaeocene-Eocene Thermal Maximum: Massive input of dissolved barium from seafloor gas hydrate reservoirs. Spec. Pap. Geol. Soc. Am. 369, 11-23 (2003).

22. Dickens, G. R., O'Neil, J. R., Rea, D. K. \& Owen, R. M. Dissociation of oceanic methane hydrate as a cause of the carbon isotope excursion at the end of the Paleocene. Paleoceanography 10, 965-971 (1995)

23. Katz, M. E., Pak, D. K., Dickens, G. R. \& Miller, K. G. The source and fate of massive carbon input during the Latest Paleocene Thermal Maximum. Science 286, 1531-1533 (1999). 
24. Hesselbo, S. P. et al. Massive dissociation of gas hydrate during a Jurassic oceanic anoxic event. Nature 406, 392-395 (2000)

25. Kvenvolden, K. A. in Gas Hydrates: Relevance to World Margin Stability and Climate Change (eds Henriet, J. P. \& Mienert, J.) 9-30 (Spec. Publ. 137, Geological Society of London, 1998).

26. Hoffman, P. F., Halverson, G. P. \& Grotzinger, J. P. Are Proterozoic cap carbonates and isotopic excursions a record of gas hydrate destabilization following Earth's coldest intervals? Comment. Geology 30, 286-287 (2002).

Supplementary Information accompanies the paper on www.nature.com/nature.

Acknowledgements We thank S. H. Zhang, H. C. Wu, G. B. Li and D. M. Liu for field assistance, and D. Mrofka and C. Valkenburg for laboratory assistance in stable isotopic analysis. We also thank M. A. Arthur and J. P. Grotzinger for comments and suggestions. This work was supported by the NSF.

Competing interests statement The authors declare that they have no competing financial interests.

Correspondence and requests for materials should be addressed to G.J. (ganqing@mail.ucr.edu)

\section{A change in the freshwater balance of the Atlantic Ocean over the past four decades}

\section{Ruth Curry $^{1}$, Bob Dickson ${ }^{2}$ \& Igor Yashayaev ${ }^{3}$}

${ }^{1}$ Woods Hole Oceanographic Institution, Woods Hole, Massachusetts 02543, USA ${ }^{2}$ Centre for Environment, Fisheries, and Aquaculture Science, Lowestoft,

NR33 OHT, UK

${ }^{3}$ Bedford Institute of Oceanography, Dartmouth, Nova Scotia, B2Y 4A2, Canada

The oceans are a global reservoir and redistribution agent for several important constituents of the Earth's climate system, among them heat, fresh water and carbon dioxide. Whereas these constituents are actively exchanged with the atmosphere, salt is a component that is approximately conserved in the ocean. The distribution of salinity in the ocean is widely measured, and can therefore be used to diagnose rates of surface freshwater fluxes $^{1}$, freshwater transport ${ }^{2}$ and local ocean mixing ${ }^{3}$-important components of climate dynamics. Here we present a comparison of salinities on a long transect $\left(50^{\circ} \mathrm{S}\right.$ to $\left.60^{\circ} \mathrm{N}\right)$ through the western basins of the Atlantic Ocean between the 1950s and the 1990s. We find systematic freshening at both poleward ends contrasted with large increases of salinity pervading the upper water column at low latitudes. Our results extend a growing body of evidence indicating that shifts in the oceanic distribution of fresh and saline waters are occurring worldwide in ways that suggest links to global warming and possible changes in the hydrologic cycle of the Earth.

The properties of Atlantic water masses have been changing-in some cases very much-over the five decades for which reliable and systematic records of ocean measurements are available. Careful analyses of observations have together revealed much about the magnitude, timing, and spatial scales of variability, and established a framework for interpreting the dynamics and kinematics underlying those changes ${ }^{4-10}$. Building upon these studies and the lengthening timeline of observations, we have evaluated the time evolution of Atlantic salinities and find evidence for long-term and large-scale changes that appear to be organized, at least in part, around the structure of the hydrologic forcing as reflected in the evaporation minus precipitation $(E-P)$ distribution.

We first present the large-scale differences in salinity that arose between the late 1950s and the 1990s along a particular transect through the deep basins of the western Atlantic from $50^{\circ} \mathrm{S}$ to $60^{\circ} \mathrm{N}$ (black line in Fig. 1c). This line was chosen with some care. It spans the maxima and minima of $E-P$ in both hemispheres ${ }^{11,12}$ (Fig. 1d). As shown, the $E-P$ maxima underlying the trade-wind belts north and south of the Equator are separated by a belt of net precipitation associated with the intertropical convergence zone; a third $E-P$ maximum follows the axis of the Gulf Stream. The main features of the surface salinity distribution result in large part from that $E-P$ distribution, so our transect crosses the regions of maximum salinity in the subtropics of both hemispheres as well as the surface salinity minima along the Equator and at both poleward ends of the line (Fig. 1c).

Figures $1 \mathrm{~b}$ and $2 \mathrm{~b}$ show the differences in salinity observed along this transect for the time period 1985-99 compared to 1955-69 as functions of density and depth, respectively. The corresponding average distributions of salinity along this transect for the time period 1985-99 are also shown; all are annotated to indicate the locations of water mass types to which we shall refer. Along the section as a whole (Figs $1 \mathrm{~b}$ and $2 \mathrm{~b}$ ), we find evidence of freshening over much of the water column at both poleward extremities of the section. In the intervening tropics and subtropics, we find that the upper ocean became more saline. These changes break down as follows.

North of $40^{\circ} \mathrm{N}$ the Atlantic water column became fresher by approximately -0.03 p.s.u. on average, reflecting the sustained freshening of LSW (see Fig. 1 legend for names of all water masses), but also of the products of Faroe-Shetland and Denmark Strait overflow from the Nordic seas which underlie it (that is, NEADW and DSOW $)^{10}$.

Towards the southern limit of the transect, the water masses that outcrop in the regions where precipitation dominates-nominally south of $25^{\circ} \mathrm{S}$ in the western South Atlantic (see Fig. 1d)-have also freshened. Over the 40-yr record, the ventilated thermocline waters, in the neutral density range $\gamma_{\mathrm{n}}=25.5-27.0 \mathrm{~kg} \mathrm{~m}^{-3}$, became less saline by more than -0.2 p.s.u.. The underlying AAIW and UCDW also show evidence of freshening, but at a comparatively reduced level of about -0.02 p.s.u.. A lack of deep-ocean measurements southward of $32^{\circ} \mathrm{S}$ in the earlier time frame precludes assessing changes below $3,000 \mathrm{~m}$ there.

In the waters of the tropics and subtropics, salinity increases observed over this period are greatest in the upper $500 \mathrm{~m}$. Salinities increased by +0.1 to +0.4 p.s.u. over four decades in all Atlantic waters exposed to the atmosphere in the high-evaporation regions between $25^{\circ} \mathrm{S}$ and $35^{\circ} \mathrm{N}$, corresponding to the density range $\gamma_{\mathrm{n}}=23.0-25.0 \mathrm{~kg} \mathrm{~m}^{-3}$. Immediately underlying this layer, the subsurface thermocline waters in the density range $\gamma_{n}=25.5-$ $27.0 \mathrm{~kg} \mathrm{~m}^{-3}$ became similarly more saline in the Northern Hemisphere. These are the SMW, whose properties are set at the sea surface in the eastern basin between $20^{\circ} \mathrm{N}$ and $30^{\circ} \mathrm{N}$ by hot, dry easterly winds from the African continent. From this source, SMW circulate westward in accordance with ventilated thermocline theory into the Caribbean and western North Atlantic ${ }^{13}$ where they are no longer in direct contact with the atmosphere, but are easily identified by a salinity maximum at depths of 100-300 m. In the South Atlantic, by contrast, maximum salinities are found at the sea surface on the western side of the basin (see Fig. 1c).

Although rising salinities are largely a feature of the low-latitude upper ocean, we find also some increase at depth between $25^{\circ} \mathrm{S}$ and $40^{\circ} \mathrm{N}$. Centred on the neutral density level $\gamma_{\mathrm{n}}=27.8 \mathrm{~kg} \mathrm{~m}^{-3}$, these elevated salinities correspond to the mixture of Atlantic and Mediterranean water masses that occupies depths 1,200-1,500 m, immediately overlying the UNADW. A 40-yr trend towards increased salinities has been documented in the deep waters of the Mediterranean Sea ${ }^{14}$ and the increase observed here reflects the trans-ocean spreading of that influence to the western boundary and southwards in the mid-depth Atlantic circulation. On our transect, salinity increases near $\gamma_{n}=27.8 \mathrm{~kg} \mathrm{~m}^{-3}$ exceed 